Greenbank, E., \& Marra, M. (2020). Addressing societal discourses: negotiating an employable identity as a former refugee. Language and Intercultural Communication, 20(2), 110-124.

https://doi.org/10.1080/14708477.2020.1722147

This is an Accepted Manuscript of an article published by Taylor \& Francis in Language and Intercultural Communication on 20 February 2020, available online:

https://www.tandfonline.com/doi/pdf/10.1080/14708477.2020.1722147

\title{
Addressing societal discourses: Negotiating an employable identity as a former refugee ${ }^{1}$
}

\author{
Emily Greenbank and Meredith Marra \\ Language in the Workplace, School of Linguistics and Applied Language Studies, \\ Victoria University of Wellington \\ emily.greenbank@vuw.ac.nz
}

\section{Key words:}

Former refugees, employable identities, societal discourses, narrative, social action, Interactional Sociolinguistics

\section{Abstract:}

This paper explores a critical area of refugee resettlement, namely securing stable, desirable employment in host nations. When telling their 'narratives of flight', our analytic focus, refugees demonstrate discursive agency and identities that conflict with a societal stereotype of vulnerability and helplessness that employers might expect. Insights suggest opportunities for new ways of supporting former refugees to find appropriate employment in a context in which their agency may be constrained and their strengths overlooked. This includes challenges to wider societal discourses and a two-way strategy where onus is placed on 'hosts' as much as on newcomers.

\section{Abstract in Arabic:}

تبحث هذه الورقة في أحد أهم المناحي المتعلقة بإعادة توطين اللاجئين، وبالتحديد الجانب المتعلق بتأمين فرص عمل ذات طابع مستقر ويتتاسب مع قدر ات اللاجئين في الدول المستضيفة. فحين بروي اللاجئون رحلة اللجوء فإنهم يبرزون إر ادة وهوية تتعارض مع ما قد يتوقعه أرباب العمل مما يسود في المجتمع من صور نمطية عنهم كالضعف و اليأس. ومن خلال هذه فإننا نجد الفرصة متاحة لإقتر اح وسائل جديدة والتي من خلالها يمكن توفير الدعم لمن قدم كلاجئ في سبيل إيجاد الوظائف اللائقة في ظروف قد تتقيد فيها إر ادتهم وتُخفل نقاط قو تهم. ويتضمن ذللك تحديات للخطاب المجتمعي السائد، بالإضافة الى استر اتيجية ثنائية الأقطاب يتم من خلالها تحميل العبء على "المضيفين" بقدر متساوي مع القادمين الجدد 
Greenbank, E., \& Marra, M. (2020). Addressing societal discourses: negotiating an employable identity as a former refugee. Language and Intercultural Communication, 20(2), 110-124.

https://doi.org/10.1080/14708477.2020.1722147

\section{Refugees and employment in New Zealand}

Securing stable, desirable employment is recognised as a key indicator of successful settlement for former refugees (those who have been refugees in the past but are now permanent residents of their countries of resettlement). However, a sense of belonging in the new home is regularly thwarted by barriers of many kinds, including linguistic and discursive obstacles. Refugees typically face a linguistic penalty (Roberts, 2013) not only in relation to a lack of proficiency in the dominant language, but also in terms of sociopragmatic proficiency, i.e. culturally-relevant ways of making meaning that are so often implicit and unrecognised by the majority, but which play a central role in successful interaction.

Recognising these challenges, the Wellington Language in the Workplace (LWP) project team has been engaged in supporting migrants in their quest for work commensurate with their qualifications and professional experience over a number of years (see J. Holmes et al., 2011; Marra, Holmes, \& Riddiford, 2011). Drawing on analyses of naturally-occurring workplace talk, the team has identified key dimensions and patterns that form the basis of teaching materials which incorporate explicit pragmatic instruction as well as training in reflexive discourse analytic techniques alongside supported internships. The goal is to encourage newcomers to become empowered members of their workplace teams, and by extension, society (Riddiford \& Newton, 2010).

To date, this work and the corresponding course have focussed almost exclusively on skilled migrants $^{1}$, in line with the government priorities they were designed to address. Political instability, climate change, and a rise in isolationist and xenophobic ideologies across the globe have resulted in increasing numbers of refugees worldwide. The rapid increase in the numbers of refugees searching for new homes in New Zealand, and an increase in the annual refugee quota by the current government, means it is timely to pay closer attention to the specific needs and experiences of refugees on their journeys from peripheral to full community membership. 
Greenbank, E., \& Marra, M. (2020). Addressing societal discourses: negotiating an employable identity as a former refugee. Language and Intercultural Communication, 20(2), 110-124.

In this paper we take a narrative sociolinguistic approach to explore the stories of former refugees and the impact of wider societal discourses on their experiences of settlement in their new country. By focusing on the (employable) identities of the refugees our goal is to consider ways of addressing the discursive barriers and gatekeeping ideologies that impact upon successful settlement.

\section{Employment and migration}

For forced migrants, the challenges involved in migration, particularly with regards to employment, can be more intense compared to voluntary migrants (see Duff, 2015; Greenbank, 2019). Refugees have little, if any, choice in their destination. They often receive little forewarning of their departure, and likely have more pressing and immediate concerns to attend to than future employment, such as their personal welfare and that of their families. Consideration of the countries in which their skills and qualifications would be valued and recognised, investigation of local labour markets, becoming acquainted with local norms and practices, and preparation for the (re)creation of useful social networks are far less possible and practical for those fleeing persecution than for those choosing to migrate for voluntary pull factors (Kunz, 1973; Lamba, 2003; Ricento, 2015). Nonetheless, once in their new homes, former refugees must contend with the local labour market, and negotiate ways to present themselves as employable in a new and likely unfamiliar environment.

Employability has been explored extensively through lenses of the (global) economy (e.g. Benner, Leete, \& Pastor, 2007; Lavy \& Yadin, 2013; Richardson, 2000), psychology (e.g. Dries, Forrier, De Vos, \& Pepermans, 2014; Fugate, Kinicki, \& Ashforth, 2004i Vanhercke, De Cuyper, \& Peeters, 2013), and education and the role of tertiary institutions (e.g. Boden \& Nedeva, 2010; Bridgstock, 2009; Brown \& Hesketh, 2004; Brown, Power, Tholen, \& Allouch, 2016; Hinchliffe \& Jolly, 2011; Moreau \& Leathwood, 2006; Tomlinson, 2010). Many of these approaches view employability from the traditional perspective of a collection of desirable skills and attributes residing within an individual (Boden \& Nedeva, 2010; L. Holmes, 2001, 
Greenbank, E., \& Marra, M. (2020). Addressing societal discourses: negotiating an employable identity as a former refugee. Language and Intercultural Communication, 20(2), 110-124.

\section{https://doi.org/10.1080/14708477.2020.1722147}

2013; Moreau \& Leathwood, 2006). We instead conceptualise the job seeker's relationship with the labour market from the perspective of identity construction.

We adopt Interactional Sociolinguistics as our lens, and take a discursive, interactional approach to identity. We conceptualise identity as a multiple, fluid and dynamic sociocultural phenomenon that emerges from and is negotiated within interaction (Bamberg, Fina, \& Schiffrin, 2011; Bucholtz \& Hall, 2005; Darvin \& Norton, 2015; De Fina, 2003), gaining meaning within social and cultural practices (Bucholtz \& Hall, 2005; LaPointe, 2010). Thus, as Michael Tomlinson (2010, p. 80) notes, "notions of employability, skills and competence only have meaning when located within socially constructed channels of inter-employee engagement and interaction." The valuable skills, attributes, and experience job seekers may 'possess' must be recognised as such by those employing or considering employing them. Viewing employability as an identity allows us to approach it as a discursive and socially situated phenomenon, which is interactionally achieved with employers, interviewers, and colleagues. Enacting a certain kind of identity entails choices of positioning of self and other (Bamberg, 1997; Lagenhove \& Harré, 1999), and the acceptance or rejection of that positioning by others, (L. Holmes, 2001; LaPointe, 2010). Reissner-Roubicek (2017, p. 61) suggests that the positioning of self and other "is a highly relevant struggle to construct an employable identity.... whether explicitly or implicitly achieved." Thus, it is important to recognise that an employable identity is not any one 'thing,' but lies in the doing of contextually-appropriate identity negotiation. While most research focuses on this identity work in workplaces and job interviews, it is not only performed in these contexts. Indeed, it may be performed in any context where employability is salient to interlocutors. For former refugees, this salience may be heightened due to their newcomer status and ongoing labour market challenges. In the context of employability-focused research, we argue that for the participants, their own employable identities factor into how they narrate themselves in interaction.

Participants in any interaction are participating within a particular social, historical, and physical context, impacted upon by extant social structure. An important form of social structure that must be navigated is that constructed through wider social discourses, or 
Greenbank, E., \& Marra, M. (2020). Addressing societal discourses: negotiating an employable identity as a former refugee. Language and Intercultural Communication, 20(2), 110-124.

\section{https://doi.org/10.1080/14708477.2020.1722147}

"socially accepted association[s] among ways of using language, of thinking, feeling, believing, valuing, and of acting that can be used to identify oneself as a member of a socially meaningful group or 'social network', or to signal (that one is playing) a socially meaningful 'role'"' (Gee, 1990, p. 143). We adopt Gee's nomenclature of Discourses (with a capital D), as distinct from discourses (with a lower-case $d$ ) which refers to everyday language in use, to discuss these wider social ideologies.

Media representation frequently depicts refugees as traumatised victims (Gabrielatos \& Baker, 2008; Greenbank, 2014). This suggests that Capital-D Discourses of what it means to be a 'refugee' tend to characterise former refugees as vulnerable, needy, and having low agency (see Greenbank, 2019 for further discussion). Discourses of Refugeehood, then, invoke helplessness and victimhood. This victim-like positioning has been reinforced by debates surrounding rights to claim asylum in various places. Discussions are predicated on the idea of 'bogus' and 'genuine' refugees (where 'bogus' refugees are assumed to be voluntary, economic migrants taking advantage of asylum-claiming rights), resulting in refugee rights advocates placing greater emphasis upon victimhood to justify refugeehood and thus state protection (Korac, 2009, p. 7). While this kind of representation can draw attention to refugees' plight and foster empathy, even if well-intentioned, it can also suggest that refugees are incapable of helping themselves (Marlowe, 2010; Pupavac, 2008), and contribute to the reproduction of social exclusion (Araeen, 2000).

One of the particular discourse activities that aligns with this view of refugees is a tellable story of flight, one which wider society might expect to invoke the stereotypes of 'genuine' refugeehood. Narratives have regularly been used as a discourse activity in which we find evidence of identity (co)construction (e.g. De Fina \& Georgakopoulou, 2008; van de Mieroop, 2009) and comprise our analytic focus.

\section{Former refugee newcomers}

This paper's data comes from the first author's wider ethnographically-informed, doctoral research into former refugees' navigation of employable identities in New Zealand. 
Greenbank, E., \& Marra, M. (2020). Addressing societal discourses: negotiating an employable identity as a former refugee. Language and Intercultural Communication, 20(2), 110-124.

\section{https://doi.org/10.1080/14708477.2020.1722147}

Participants were identified by those working and volunteering in refugee resettlement initiatives and were suggested due to their current status as job seekers or having recently found work after a stretch of unemployment post arrival in New Zealand.

The four participants included in the analysis we present come from four different countries in Africa and the Middle East, and are all now in their mid-late 30s. Isaac ${ }^{2}$ fled his home country of Eritrea in his late teens, spending some years in a refugee camp in Sudan before being resettled. He worked various seasonal and cleaning jobs in New Zealand before completing a bachelor's degree in Political Science and going on to work in an employment union. Kelly was born in Kuwait to fairly affluent Palestinian parents who had migrated there for work. Her family left Kuwait following the Gulf War when she was a child, coming to New Zealand as refugees. Beginning in her teens she spent a number of years in Palestine, getting married and having children, before returning to New Zealand. She completed a bachelor's degree in Business and was looking for work when we met. Omar is from Syria, and received his education in engineering there, before spending a number of years working as an engineer, and later chief engineer, on freight ships. He and his wife and children left Syria to claim asylum and were later resettled in New Zealand. He has been able to find employment as an engineer, albeit well below his skill and qualification level. Arwa comes from a Middle Eastern country ${ }^{3}$ which she left when she was in her 20 s to study towards a Master's degree and then PhD in Computer Science at a university in Malaysia. Upon completing her education, she claimed asylum, not wishing to return to her home country, and was eventually resettled in New Zealand. She has not been able to access employment in her qualification area since arrival.

The participants were interviewed between three and eleven times over an 18-month period, depending on their availability. They were aware of the research's focus on former refugees' employability and labour market experiences. Following an ethnographic ethos within a social constructionist, interactional sociolinguistic framework, interviews were approached as conversational, social encounters of meaning-making where that meaning is coconstructed by both the interviewer and the interviewee (Holstein \& Gubrium, 1995; Mann, 
Greenbank, E., \& Marra, M. (2020). Addressing societal discourses: negotiating an employable identity as a former refugee. Language and Intercultural Communication, 20(2), 110-124.

\section{https://doi.org/10.1080/14708477.2020.1722147}

2010; Talmy, 2010). The first 'interview' with each of these participants was semi-structured, covering a range of topics on the participants' background in a style akin to conversation, and interactions thereafter were largely conversational and spontaneous. All of the data in this paper comes from the participant's first interview with interpretations supported by analysis of the fuller data set.

\section{Identity in narrative}

We focus specifically upon narratives that emerge within interaction. Narratives are stories we tell about ourselves and others, and through which we make sense of our experiences and our place in the social world. They connect past events to our contemporary senses of self, and help in the imagining of our possible futures (Pomerantz, 2012; Schiffrin, 1996). They are thus important and rich sites within which to explore the co-constructed negotiation of identity generally, and an employable identity specifically. While the content of narratives can of course be illuminating, from an identity perspective, they are invaluable for examining the positioning of self (both as narrator and protagonist) and other (both present interlocutor(s) and other characters within the storyworld), as well as the taking up or rejection of dynamic identity positions (Bamberg, 2011a; De Fina, 2003). Exploration of narrative allows us to consider how narrators position themselves relative to the wider Discourses which permeate all interaction, and this is particularly pertinent for our focus on the experiences of former refugees.

To examine the ways in which this study's participants take up identity positions, we analyse stories told by the participants about leaving their countries of origin, or a secondary country outside their country of origin. These can be described as narratives of flight. Narratives of flight are a rich data source for exploring people's senses of self, providing speakers with the opportunity to negotiate an empowered identity in discourse (Lanza, 2012, p. 289), as well as, for the researcher, "[providing] insight into how speakers position themselves to Discourse within the local discourse of interaction" (Lanza, 2012, p. 288). As we will see, the participants are aware of and position themselves relative to wider Discourses, in some cases aligning with and sometimes distancing themselves from them. 
Greenbank, E., \& Marra, M. (2020). Addressing societal discourses: negotiating an employable identity as a former refugee. Language and Intercultural Communication, 20(2), 110-124.

In these narratives the participants are not directly indexing their employable identities or attempting to enact employability. However, we argue that employability is salient and contextually-relevant throughout their narratives, as the participants were all aware of the wider research goals (namely investigating the employable identity construction of former refugees as described above). This awareness must have been particularly salient in these first interviews. Further, the themes that emerge within the narratives mirrored those that arose in later explicit discussion of employment and employability. For illustrative purposes, we believe that the participants' narratives of flight display their self-positioning vis-à-vis Discourses of Refugeehood at their most explicit.

Bamberg (2011a, p. 106) observes that speaking subjects, although agentively engaging in narrative practices (and indexing positions in relation to dominant Discourses), must either employ narrative devices "that lean toward a person-to-world direction of fit, or they pick devices that construe the direction of fit from world-to-person," or somewhere in between the two. A person-to-world fit depicts high agency, portraying a 'heroic self' who is strong, in control, capable of acting upon the world and transforming their own circumstances. At the other end of the continuum, a world-to-person fit presenting low agency portrays the speaker in a victim role, not only less influential and powerful but also less blame-worthy. That is, a world-to-person position depicts that speaker or character as being acted upon by the world, as a recipient of action rather than as the architect of it. Bamberg (2011a, 2011b) describes the choice between high- and low-agency self-position in discourses as an "agency dilemma."

This dilemma is particularly pertinent in the consideration of former refugees' negotiation of employable identities. Former refugees must discursively navigate the structural challenges that they face, at the same time as presenting themselves as capable, competent, agentive - and employable. This may be a dilemma facing any job seeker, but the structural barriers faced by former refugees are greater. They include having to navigate expectations and Discourses surrounding what it is to be a refugee. For example, treading a fine line between, 
Greenbank, E., \& Marra, M. (2020). Addressing societal discourses: negotiating an employable identity as a former refugee. Language and Intercultural Communication, 20(2), 110-124.

\section{https://doi.org/10.1080/14708477.2020.1722147}

on the one hand, presenting a highly agentive, proactive, and independent self that counteracts Discourses of Refugeehood and may jeopardise access to support, and on the other hand, presenting a low agency, vulnerable self that invites sympathy and offers of assistance but may undermine negotiation of an employable identity and acceptable sense of self.

\section{Narratives of flight}

What might be considered a 'typical' narrative of flight was told by one of this study's participants, Isaac. Isaac managed to convince his family that it was not safe for him to stay in Eritrea, and arranged to leave the country. He travelled several hundred kilometres on a bus from his home city to the border with Sudan using a forged travel permit. He was almost caught at the last checkpoint when his travel document was taken away to be checked by a soldier, but he re-boarded the bus and left before the soldier returned. Upon arriving at a town near the border, he paid a smuggler who took his money and disappeared. He managed to find another smuggler who was finally able to get him across the border.

Isaac's narrative of flight from Eritrea is well-honed and skilfully told. He has told this story of escape and luck many times, both privately and publicly, and the narrative follows a typical Labovian narrative structure. Labov (2014, p. 204) noted that at a minimum, a narrative will contain "a sequence of two clauses which are temporally ordered", but a 'fully formed" narrative may contain an abstract (a clause or two summarising the story), an orientation (identification of the setting, time, persons), one or more complicating actions, an evaluation (the point of the narrative), a resolution, and a coda (a signal that the narrative has finished, and possibly a connection between the end of the story and the present time) (Labov, 2014; Labov \& Waletsky, 1967). The story that Isaac tells, in theme and structure if not in detail, fits well with generally held ideas about what the refugee experience entails (Eastmond, 2007; Nayeri, 2017). He aligns with his (former) refugee identity in the telling and makes little attempt to allay this storyworld alignment with any competing, contemporary (interviewcontext) identity positions. We do not present analysis here for the sake of space, but 
Greenbank, E., \& Marra, M. (2020). Addressing societal discourses: negotiating an employable identity as a former refugee. Language and Intercultural Communication, 20(2), 110-124.

\section{https://doi.org/10.1080/14708477.2020.1722147}

mention it to acknowledge that some refugee-background storytellers tell these stories 'as expected,' containing all of the typical Labovian elements, including several complicating actions.

It is notable that while Isaac's narrative fits the stereotype, those of the others in the wider data set did not. In most cases the participants appeared to resist 'leaning in' to their refugee identities. In answering (or avoiding) the interviewers' (direct or indirect) questions about how they came to be a refugee (i.e. to tell their stories of flight), Omar, Kelly, and Arwa took the opportunity to tell a different story about themselves - stories of strength, of competence, and of resilience.

\section{Omar}

Omar, like Isaac, tells a story of flight which in some ways aligns with Discourses of Refugeehood in terms of content, but he continually orients away from aligning with an imagined community (Anderson, 1991) of refugees. When Omar returned home after finishing what turned out to be his final contract as a ship engineer, a massacre took place in his city. This massacre motivated Omar to leave Syria with his family and travel to Egypt, where they claimed refugee status and lived for almost two years, before eventually being resettled in New Zealand. In telling this story of flight, Omar makes clear the substantial danger that prompted his family's flight, but nonetheless interactionally distinguishes his family from Discourses of Refugeehood, and orients to an identity of capability and competence in the face of danger. In the following excerpt he describes his family's decision to leave Syria after the massacre:

\section{Excerpt 1; 4 June 2016; 9.05-9.31}

1. Omar: after that I: tell myself I have to + take my family

2. IV: $\mathrm{mm}=$

3. Omar: =my children my wife and my children + and went + directly

4. from Syria to Egypt + legally + not illegally legally by airplane 
Greenbank, E., \& Marra, M. (2020). Addressing societal discourses: negotiating an employable identity as a former refugee. Language and Intercultural Communication, 20(2), 110-124.

Positioning himself as a competent and rational man with respect to his relationship and responsibility to his family (lines 1 and 3), Omar discursively disaligns with an imagined community (Anderson, 1991) of other refugees and asylum seekers by emphasising that his family travelled directly to Egypt, and by repeating that they travelled legally, not illegally and that their trip was by airplane (line 4), dialogically responding to an absent challenge to their legal status. This description indexes by implication, and distances him from, the unmentioned (and at the time, very prevalent in the media) image of hundreds of thousands of refugees - Syrians and others - travelling by land and by sea to an ambivalent and often hostile Europe. Omar here navigates Bamberg's (2011b) agency dilemma by orienting away from Discourses of what it is to be a refugee (particularly media Discourses), and instead orients to an identity of independence and competence in a crisis, as he looked after his family.

A little later, after describing his family's time in Egypt, Omar came to the point in his story at which his family came to New Zealand, wherein we see Omar discursively reject the interviewer's implicit invitation for him to align with refugeehood.

Excerpt 2; 4 June 2016; 10.17-10.49

1. Omar: an::d they sent us to + New Zealand

2. IV: ok (1) so that would have been sort of just before + I guess maybe

3. Omar: I spent about twenty months in Egypt + //after II came here

4. IV: /did youll (2) so tha-so you must have come here

5. just as the kind of the whol:e + refugee crisis //was/ was starting (1)

6. Omar: /yeahll

7. IV: that must have been quite a (2) strange thing to witness on the media

8. Omar: for me see + ah to go outside of Syria is not a big issue

9. IV: $\mathrm{mm}$

10. Omar: because I used to 
Greenbank, E., \& Marra, M. (2020). Addressing societal discourses: negotiating an employable identity as a former refugee. Language and Intercultural Communication, 20(2), 110-124.

\section{https://doi.org/10.1080/14708477.2020.1722147}

11. IV: yeah

12. Omar: travelling but this is the first time I take my family with me

Beginning in line 2, the interviewer begins a highly mitigated attempt to ask a question (evidenced through a quick succession of markers of uncertainty sort of, I guess and maybe), before being cut off by Omar either redirecting the conversation, or misinterpreting the aborted question as pertaining to his time spent in Egypt (line 3). Following a two-second pause which would have allowed Omar to continue narrating, had he wished to, the interviewer then relaunched the question, with the expectation that Omar would pick up on their cue and discuss his relationship to the wider exodus of Syrians from Syria. Initially, the interviewer attempted to be delicate in her approach lest discussing the topic be distressing for him, and then as the long-winded circuitous question continued and the interviewer observed no uptake in Omar's body language and a one syllable acknowledgement of the times matching up (line 6), began to feel uncomfortable about what she was asking. Her discomfort is evident in the false start, pauses, and mitigating kind of. The interviewer begins, in line 7, to respond to her own question by suggesting how Omar might have experienced media coverage of the event, but in fact has changed course once more part way through an utterance (unwilling to project hardship when receiving no uptake) to arrive at a much-diluted conclusion that it must have been a strange experience. Through Omar's lack of visual or verbal uptake and the interviewer's own backing away from the question even while asking it, the interactants co-construct distance between Omar and his family, and the (media coverage of the) so-called Syrian refugee crisis, and thus Discourses of Refugeehood. Omar then reinforces this rejection of the interviewer's position by redirecting the conversation toward issues of resettlement (lines $8,10,12$ ), positioning himself as a worldly and experienced traveller whose only challenge was the company of his less welltravelled family. Although discursively encouraged to do so through the interviewer's convoluted line of questioning, Omar rejects the invitation to align with a refugee identity, and agentively reorients to an identity of competence.

Kelly 
Greenbank, E., \& Marra, M. (2020). Addressing societal discourses: negotiating an employable identity as a former refugee. Language and Intercultural Communication, 20(2), 110-124.

\section{https://doi.org/10.1080/14708477.2020.1722147}

Kelly also orients towards high agency, capable identity positions when she describes her return to New Zealand. Her ostensive narrative of flight is not the story of how she came to be a refugee, but rather her later flight as an adult, from Palestine in a state of war, and equally (or perhaps more so) from her husband. When Kelly was a teenager her family moved from New Zealand to Palestine, a country she had never visited. She finished high school in Palestine, and then married and had children. Kelly described a backdrop of escalating political tension in Palestine, noting that she saw little of it because her husband kept her basically locked up (her words). However, she described her storyworld restricted circumstances in a tone which sounded as if she were on the verge of laughter the whole time. In doing so, she discursively reframes the situation in a less serious light, as if it were almost comical, perhaps allowing Kelly-as-narrator to save face within the interaction (Warner-Garcia, 2014).

Kelly was explicit with the interviewer about her strategy for dealing with her unhappy marriage and the fact that her husband would not allow Kelly and their children to leave Palestine despite the war: to make her husband's home life as unpleasant as possible. While Kelly's parents were still in the country her husband would complain to them about their daughter's behaviour, and they would tell her to behave (Kelly's term), but once they had left he was unable to access this support. Although she narrates a scenario in which she is essentially a prisoner, by creating a storyworld in which she is able to psychologically outwit her husband, Kelly interactively negotiates an identity of resilience and resourcefulness, and as powerful in relationship to her husband who physically controlled her body but was unable to control her spirit 4 .

This identity work is clear in the following excerpt in which Kelly describes her husband's eventual acquiescence:

Excerpt 3; 8 April 2016; 32.17-32.44

1. Kelly: he just gave up and he thought + that's it go + to + ah New Zealand 
Greenbank, E., \& Marra, M. (2020). Addressing societal discourses: negotiating an employable identity as a former refugee. Language and Intercultural Communication, 20(2), 110-124.

\section{https://doi.org/10.1080/14708477.2020.1722147}

2. but (1) so I had a bit of money? + he took my money

3. and he said this money is my insurance that you will send me a visa

4. (1) I sent him a visa + and I told him you can shove the money up your ass

5 . if I don't want no money I don't want anything to do with you

6. and + that's it [laughs] yeah

Kelly uses adverbial just phrasing to describe her husband's surrender in line 1 . While frequently used as a minimiser, just here has the effect of emphasising his failure to control Kelly (Lindemann \& Mauranen, 2001; Vine, 2017), positioning him as weak, and as the loser of their battle of wills. Kelly narrates from a powerful position as she constructs her husband's inner dialogue (line 1), that's it, wording she repeats in her own constructed dialogue (directed towards her husband) in line 6 to indicate the very end of their relationship. These two instances of that's it bookend her husband's final attempt to control her in the storyworld, and Kelly-as-protagonist's repeating of her husband's words discursively reassigns the power of declaring 'the end' from the husband to herself. Kelly's reclamation of this final power play by both sending him the visa and rejecting the money he had withheld seems to construct her husband as pathetic and desperate, and herself by contrast as in control, and on the moral high ground (having sent him the visa because it was the right thing to do for her children, and not because he was wielding any financial power over her). Her violent (reported) language directed toward her husband (you can shove the money up your ass, line 4) underscores her highly agentive position as protagonist and the force of her rejection of his power play. In addition, we would argue that Kelly's use of double negative I don't want no money in line 5 is a kind of double-voiced (Bakhtin, 1981) performance of a resolute or 'tough' position, indexing the covert prestige of non-standard English varieties (Labov, 1973; Trudgill, 1974). Finally, Kelly's laughter following this description of the end of the relationship on her terms has the interactional effect of both ridiculing her husband's narrated actions and mitigating Kelly's strongly-worded rejection (Billig, 2005; Chafe, 2003). Thus, instead of discursively encouraging pity for her narrated struggle, she claims for herself a more powerful role, orienting away from victimhood and vulnerability. 
Greenbank, E., \& Marra, M. (2020). Addressing societal discourses: negotiating an employable identity as a former refugee. Language and Intercultural Communication, 20(2), 110-124.

https://doi.org/10.1080/14708477.2020.1722147

\section{Arwa}

While in telling stories of flight Omar discursively oriented away from aligning with an imagined community of refugees, and Kelly framed her story in such a way as to describe an ideological victory (and physical escape from) her husband, Arwa resisted telling such a story at all. When asked by the interviewer about her motivations for leaving her country of origin, Arwa repeatedly oriented away from refugee-related Discourses which index vulnerability and powerlessness, and instead positioned herself as capable and academic. Each time that the interviewer explicitly or implicitly requested a story of flight, Arwa redirected the focus to the academic 'pull factor' of studying in another country, or changed the topic. At one point she spoke briefly of restrictions on clothing and criticising authority in her home country. She alluded to danger with some levity, saying that anyone just can take gun and [2 $x$ gunshot noise] bye bye + finish, employing cartoonish gunshot sounds and the playful, childlike expression bye bye to illustrate death. However, she swiftly reoriented to her academic identity a moment later.

Upon the interviewer's third attempt to elicit information about any 'push factors' for leaving, Arwa shuts down further questioning by stating that it is a long story, with the interactional effect of indicating her lack of intention to elaborate.

Excerpt 4; 16 May 2016, 18:03-18:22

1. IV: ok + so why did you say it wasn't safe for you to go back to [country]

2. Arwa: because I told you the situation now is dangerous

3. IV: ok=

4. Arwa: =anyone just can kill anyone and then now + it's it's it's long long story

5. IV: ok

6. Arwa: it's really long story

In line 1 the interviewer makes a final attempt to gather more details about why Arwa did not wish to return to her country of origin, which could be taken to imply that the narrative 
Greenbank, E., \& Marra, M. (2020). Addressing societal discourses: negotiating an employable identity as a former refugee. Language and Intercultural Communication, 20(2), 110-124.

\section{https://doi.org/10.1080/14708477.2020.1722147}

evidence she has provided is not sufficient for her to fill the expected image of a refugee. However, this positioning is rejected by Arwa, as she repeats - and states that she is repeating - that the country is dangerous (line 1). She shuts down further questions by saying twice that it is a long story (lines 4 and 6), in this context a Labovian coda firmly moving away from her narrative-world departure from her country of origin and back to the present (Labov \& Waletsky, 1967; see also Puvimanasinghe, Denson, Augoustinos, \& Somasundaram, 2014). At this point, it is clear that this is not a topic Arwa wishes to unpack any further, and the interviewer abandons the attempt to gain a clearer picture of Arwa's motivations for leaving.

Although the interactions with Arwa were guided to a certain extent by the interviewer's questions, Arwa could - and did - agentively take up discursively powerful positions by avoiding, redirecting or refusing to answer, and guiding the interviewer's focus to the stories she wanted to tell (Finlay, 2012; Lammers, 2007; Talmy, 2010). In this way she was able to construct an academic and highly employable identity and avoid orienting to a (former) refugee identity associated with victimhood.

\section{The impact of wider societal Discourses}

It has become evident in this paper's narrative of flight data that former refugees are not necessarily inclined to orient to the wider social Discourses surrounding refugeehood that may be expected of them by a non-refugee audience, whether the majority group member who is interviewing them, or an imagined addressee. It is important to appreciate that, individually, most people of refugee background are people who, up until a certain point in their lives, had the same outsider's view of what it means to be a refugee as those who have not experienced flight. That is, up until the circumstances that necessitated their flight, those who eventually experience refugeehood may have had the same external view of the imagined community (Anderson, 1991) of refugees that perhaps the media plays the largest role in shaping. It is unsurprising, then, that in the telling (or in the avoidance of telling) of stories of flight, people of refugee background may not feel particularly inclined to orient towards Discourses of Refugeehood, or enact victim-like, powerless identities that threaten 
Greenbank, E., \& Marra, M. (2020). Addressing societal discourses: negotiating an employable identity as a former refugee. Language and Intercultural Communication, 20(2), 110-124.

\section{https://doi.org/10.1080/14708477.2020.1722147}

to drown out all other aspects of self. Although Discourses surrounding refugeehood may have their roots in benevolent discourse that is spurred by, and aimed at fostering, empathy and tolerance, these representations can hinder recognition of refugees' skills and ability to contribute to their host societies (Greenbank, 2014, 2019), and can in fact be an "impediment to...standings as full members of society" (Fraser, 2003, p. 31; cited in Marlowe, 2010, p. 7). It may thus impact upon an individual's capacity to navigate the labour market successfully and enact a locally-useful employable identity. As mentioned above, former refugees are in a position where they must discursively navigate the structural challenges that they face, at the same time as presenting themselves as capable, competent, agentive and employable Bamberg's (2011b, 2011a) agency dilemma. If Discourses of Refugeehood suggest that a lowagency, victim-like refugee (with a believable narrative of flight) is the epitome of a legitimate refugee, then a refugee who exercises agency and shows no visible signs of victimhood - perhaps attempting to enact a locally-valuable employable identity - perhaps invokes the notion of an illegitimate refugee. This puts refugees and former refugees in a situation where they may have to choose between orienting towards their experiences of refugeehood, or exercising agency, acting upon the world, and directing their own lives, and thus risking inadvertent orientation to refugee 'illegitimacy' (for further discussion, see Greenbank, 2019).

In earlier work, for example, our colleague in the Language in the Workplace team, Janet Holmes (2015), noted discursive evidence of benevolent racism that meant that New Zealand employers and colleagues unintentionally created barriers to full participation in the workplace by treating skilled migrant interns as 'guests' rather than members of the community (see also Marra, 2012). For former refugees, being treated not only as guests, but also as guests to be pitied (albeit with the best of intentions), is potentially even more of a barrier.

While Omar's narrative includes the expected elements of danger, flight, dealing with the UNHCR, and eventual arrival in New Zealand, he orients away from aligning himself and his family with an imagined community of refugees. Omar uses his narrative of flight to 
Greenbank, E., \& Marra, M. (2020). Addressing societal discourses: negotiating an employable identity as a former refugee. Language and Intercultural Communication, 20(2), 110-124.

\section{https://doi.org/10.1080/14708477.2020.1722147}

negotiate a competent, worldly identity, and in doing so orients to a sense of self that is resilient and equipped to deal with the challenges of resettlement, quite a contrast to the expectation of vulnerability. In Kelly's case, her actual return to New Zealand is passed over entirely in her story. The literal war that (at least in part) motivated Kelly to leave Palestine is also backgrounded as she focuses the narrative on her victory over her husband. Kelly describes some objectively terrible circumstances but does not portray the storyworld conditions as pitiable, or traumatic, nor position herself as vulnerable, or a victim. Instead, the telling of this story creates an opportunity to negotiate an identity of independence, resilience, and strength. In her story it is a gender identity that is foregrounded rather than a refugee identity. Finally, Arwa repeatedly, indirectly declined the interviewer's request to tell a narrative of flight at all.

Spector-Mersel (2011, p. 174) claims that in telling a story we aim for a 'valued end point', i.e. the point of the story being told, which "may refer to the core of the identity to be claimed through the story." The telling of a narrative requires (often unconscious) selection 'mechanisms' (Spector-Mersel, 2011, p. 174, following Sarbin, 1986). Omission and silencing are two of these, in which periods of life and events are not reported because they are irrelevant to the story's end point or because they contradict it, respectively ${ }^{5}$. Arwa's choice to repeatedly avoid or redirect the interviewers' questioning about her reasons for leaving her country of origin could thus be rooted in a mismatch between the identity positions this telling would oblige her to take up, and the identity 'end point' she is trying to achieve within the interaction, seemingly the successful negotiation of an academic, capable identity. Of course, the participants' experiences may be painful to retell, and certainly necessarily involved "separation from family and friends, and the loss of home, community, and country" (Puvimanasinghe et al., 2014, p. 192). When retelling periods of a life story that have a negative impact upon sense of self, narrative avoidance or the construction of 'counternarratives' can assist former refugees to orient to new or more acceptable identities that are not defined by trauma and refugeehood (Bamberg, 2004; Puvimanasinghe et al., 2014). 
Greenbank, E., \& Marra, M. (2020). Addressing societal discourses: negotiating an employable identity as a former refugee. Language and Intercultural Communication, 20(2), 110-124.

\section{https://doi.org/10.1080/14708477.2020.1722147}

\section{Social action: A two-way approach}

The narratives described above are just one example of the many narratives that can be found in the data set. These narratives have provided rich examples of the ways in which former refugees can and do resist wider social Discourses of Refugeehood, Discourses which suggest vulnerability and victimhood. Insidious and 'out-of-sight,' capital-D Discourses not only emerge in explicit discussion of, in this case, refugeehood, but rather impact upon the ways that former refugees position themselves and are positioned by others across interactional contexts. The implications for negotiating locally-valuable employable identities are clear.

Through the analysis of the data we identify powerful societal discourses/Discourses which create barriers to the former refugees' ability to negotiate a successful employable identity. Our experience tells us that supporting the refugees without addressing wider societal constraints and patronising Discourses may end up being a fruitless endeavour. In our earlier work described in the opening to this paper, it was important that in attempts to support skilled migrants (and more latterly semi-skilled migrants), we also targeted the employers of these potential employees. In line with the New Zealand government's Settlement National Action Plan (Department of Labour, 2007), our efforts have always involved creating resources and providing guidance aimed at both groups; identity construction is a negotiation between parties and focusing on just one side ignores the interactional role of the other.

In terms of the former refugees who are our focus here, change means a concerted bidirectional approach to address these unhelpful ideological barriers. If societal Discourses are to be changed we need to address at the very least: the image of refugees as lacking competence despite strong skill sets and previous employment; the conceptualisation of the participants and people like them as pitiable and vulnerable rather than proactive and strong individuals who have overcome enormous odds; and most importantly perhaps an 
Greenbank, E., \& Marra, M. (2020). Addressing societal discourses: negotiating an employable identity as a former refugee. Language and Intercultural Communication, 20(2), 110-124.

https://doi.org/10.1080/14708477.2020.1722147

acknowledgment that they are complex human beings, with complex social relationships, who are more than just the refugee label they are assigned.

In practice, the previous applications of our analysis have been most successful in industries in which there are recognised labour shortages and a corresponding desire by employers to attract migrants to fill employment gaps (aged care, building, tourism). However, for many former refugees their desired employment is not in these industries. It is important to recognise the motivations of the majority group members who are the most typical employers and whose attitudes may create barriers to employment. These societal attitudes are deeply held, and as we saw, even the speech of the interviewer (whose goal in the research was to support refugee employment) included false starts and reworking of questions because of the ingrained ideologies the questions represented and which she was recognising as she spoke. We recognise therefore that there are enormous challenges inherent in the kind of societal change we advocate, including the investment of both majority group members and refugees to contest and renegotiate these disabling and patronising Discourses. In his work with foreign domestic helpers in Hong Kong, Ladegaard (2012, see also 2017) applies the concept of "enforced" identities. This seems like a useful description for the identity struggles faced by the former refugees in our data. Arguably, the Discourses we describe within our analyses play a central role in monitoring, patrolling and defending boundaries (see J. Holmes \& Marra, 2017), creating barriers for those who want to transition into a new context and negotiate an (employable) identity. While acknowledging the boundaries is a first step, we need to consider ways of removing them, or at least making them passable.

Currently, the effort involved in constructing a successful employable identity seems to reside with refugees alone (albeit with the help of institutions and agencies charged with providing support). Despite the discursive agency exhibited in the narratives we have discussed, it must be acknowledged that an unequal burden is placed on the former refugees 
Greenbank, E., \& Marra, M. (2020). Addressing societal discourses: negotiating an employable identity as a former refugee. Language and Intercultural Communication, 20(2), 110-124.

\section{https://doi.org/10.1080/14708477.2020.1722147}

who are already marginalised in their status as newcomers to society. And as noted, the New Zealand government has recently increased the annual refugee quota so the numbers facing this challenge will continue to grow. It seems that success for this steadily increasing section of the population requires changes in attitudes as well as structural/institutional power.

Our analysis offers real life examples of larger trends, and trends which the agencies with whom we work are aware, at least at some level. The applications we have worked on to date $^{6}$, have been collaborative and (we would like to think) empowering for both employees and employers. We argue for the importance of a combined approach involving academics (here, our applied sociolinguistic approaches), employers and the government departments with whom we work who can influence policy (especially Immigration New Zealand), and the organisations at the 'coalface' for managing refugee employment issues (like our partners in Red Cross Refugees). It will take a multipronged approach to create societal change, and the burden for employability should not rest on the former refugees. Despite the discursive attempts and agency we see in their narratives, these people cannot carry sole responsibility for change in the negotiation of their identities. The New Zealand government is investing in the employability of newcomers to acknowledge the importance of full participation in society. For former refugees we know that successful employment, however, needs deeper and wider investment which includes commitment including and beyond economic measures.

\section{Coda}

At the point of submitting this article, a tragic terrorist attack took place in two mosques in Christchurch, New Zealand. While it is still too early to offer any analysis of the situation, it is worth noting that one of the immediate reactions from the government, the media and the public, was that society needed to change. While our argument about social action above may have seemed like a commendable, but not necessarily an easily-accomplished, goal, we 
Greenbank, E., \& Marra, M. (2020). Addressing societal discourses: negotiating an employable identity as a former refugee. Language and Intercultural Communication, 20(2), 110-124.

https://doi.org/10.1080/14708477.2020.1722147

note that the reaction we have experienced so far suggests there is appetite for positive societal change. 
Greenbank, E., \& Marra, M. (2020). Addressing societal discourses: negotiating an employable identity as a former refugee. Language and Intercultural Communication, 20(2), 110-124.

\section{https://doi.org/10.1080/14708477.2020.1722147}

\section{Notes}

Acknowledgement

As always, we would like to express our sincere gratitude to the participants who cooperated and collaborated with us in this research. We also thank our colleagues in the Language in the Workplace team (Janet Holmes and Bernadette Vine) who have contributed to our understanding and offered feedback on our analysis. We are particularly grateful to Shelley Dawson for the feedback and support she provided to us during the preparation of this paper, and we thank Mohammed Nofal for translating this paper's abstract into Arabic as the most common language of our participants. The doctoral research from which the data was taken was funded by a Doctoral Scholarship from Victoria University of Wellington.

Transcription conventions

\begin{tabular}{|c|c|}
\hline+ & $\begin{array}{l}\text { short pause up to one second } \\
\text { e.g. A: so I told her + don't put it there }\end{array}$ \\
\hline (1) & $\begin{array}{l}\text { pause one second or longer, where number of seconds } \\
\text { e.g. A: but she wasn't (2) she wasn't even listening }\end{array}$ \\
\hline wha- & $\begin{array}{l}\text { hyphen indicates cut off word, both self-interruption and other speaker } \\
\text { interruption } \\
\text { e.g. A: I didn't know wha- + I couldn't tell what was going on }\end{array}$ \\
\hline $\begin{array}{l}/ /[\mathrm{x}] \backslash \\
/[\mathrm{x}] \|\end{array}$ & $\begin{array}{l}\text { indicates overlapping speech } \\
\text { e.g. A: and if you want to come //youl can ok } \\
\qquad \text { B: /yep II + yep }\end{array}$ \\
\hline $\begin{array}{l}1 / /[x] \Lambda^{1} \\
1 /[x] \|\left.\right|^{1}\end{array}$ & $\begin{array}{l}\text { indicates multiple overlaps in one section } \\
\text { e.g. A: then after I came back }{ }^{1} / / \mid \text { saw }\left.\right|^{1} \text { that the other one }{ }^{2} / / \text { was }\left.\right|^{2} \text { gone } \\
\qquad \text { B: }{ }^{1} / \text { yeah } \|{ }^{1}+{ }^{2} / \mathrm{mm}^{2}\end{array}$ \\
\hline [laughs] & $\begin{array}{l}\text { square brackets with text in italics indicate paralinguistic and relevant } \\
\text { non-verbal features }\end{array}$ \\
\hline
\end{tabular}


Greenbank, E., \& Marra, M. (2020). Addressing societal discourses: negotiating an employable identity as a former refugee. Language and Intercultural Communication, 20(2), 110-124.

https://doi.org/10.1080/14708477.2020.1722147

\begin{tabular}{|l|l|}
\hline & e.g. A: yeah [laughs] but it wasn't until later that [clears throat] I realised \\
\hline so:: & $\begin{array}{l}\text { colons following letter and words indicate that sound has been drawn out } \\
\text { e.g. A: he was there for a re::ally long time }\end{array}$ \\
\hline$?$ & $\begin{array}{l}\text { High rising terminal, i.e. a word of phrase that ends with a rising pitch } \\
\text { intonation (may or may not be a question) } \\
\text { e.g. then he picked it up? and saw it was broken? }\end{array}$ \\
\hline CAPITALS & $\begin{array}{l}\text { Words spoken with emphasis; louder than surrounding speech } \\
\text { e.g. A: but I had said the FIRST one }\end{array}$ \\
\hline
\end{tabular}

References

Anderson, B. (1991). Imagined communities: Reflections on the origin and spread of nationalism (Revised). London: Verso.

Araeen, R. (2000). The art of benevolent racism. Third Text, 51, 57-64.

Bakhtin, M. (1981). The dialogic imagination: Four essays. Austin, TX: University of Texas Press.

Bamberg, M. (1997). Positioning Between Structure and Performance. Journal of Narrative and Life History, 7(1-4), 335-342.

Bamberg, M. (2004). Considering counter narratives. In M. Bamberg \& M. Andrews (Eds.), Considering counter-narratives: Narrating, resisting, making sense (pp. 351-371). Amsterdam: John Benjamins.

Bamberg, M. (2011a). Narrative practice and identity navigation. In J. A. Holstein \& J. F. Gubrium (Eds.), Varieties of Narrative Analysis (pp. 99-124). Thousand Oaks, CA: Sage.

Bamberg, M. (2011b). Who am I? Narration and its contribution to self and identity. Theory \& Psychology, 21(1), 3-24. 
Greenbank, E., \& Marra, M. (2020). Addressing societal discourses: negotiating an employable identity as a former refugee. Language and Intercultural Communication, 20(2), 110-124.

\section{https://doi.org/10.1080/14708477.2020.1722147}

Bamberg, M., Fina, A. D., \& Schiffrin, D. (2011). Discourse and identity construction. In S. J. Schwartz, K. Luyckz, \& V. L. Vignoles (Eds.), Handbook of identity theory and research (pp. 177-199). New York, NY: Springer.

Benner, C., Leete, L., \& Pastor, M. (2007). Staircases or treadmills?: Labor market intermediaries and economic opportunity in a changing economy. New York, NY: Russell Sage Foundation.

Billig, M. (2005). Laughter and ridicule. London: Sage Publications.

Boden, R., \& Nedeva, M. (2010). Employing discourse: Universities and graduate 'employability.' Journal of Education Policy, 25(1), 37-54.

Bridgstock, R. (2009). The graduate attributes we've overlooked: Enhancing graduate employability through career management skills. Higher Education Research \& Development, 28(1), 31-44.

Brown, P., \& Hesketh, A. (2004). Mismanagement of Talent: Employability and Jobs in the Knowledge Economy. Oxford: Oxford University Press.

Brown, P., Power, S., Tholen, G., \& Allouch, A. (2016). Credentials, talent and cultural capital: A comparative study of educational elites in England and France. British Journal of Sociology of Education, 37(2), 191-211.

Bucholtz, M., \& Hall, K. (2005). Identity and interaction: A sociocultural linguistic approach. Discourse Studies, 7(4-5), 585-614.

Chafe, W. (2003). Laughing while talking. In D. Tannen \& J. E. Alatis (Eds.), Linguistics, language, and the real world: Discourse and beyond (Georgetown University Round Table on Languages and Linguistics) (pp. 36-49). Washington, DC: Georgetown University Press.

Darvin, R., \& Norton, B. (2015). Identity and a model of investment in applied linguistics. Annual Review of Applied Linguistics, 35, 36-56.

De Fina, A. (2003). Identity in Narrative. Amsterdam: John Benjamins.

De Fina, A., \& Georgakopoulou, A. (2008). Analysing narratives as practices. Qualitative Research, 8(3), 379-387. 
Greenbank, E., \& Marra, M. (2020). Addressing societal discourses: negotiating an employable identity as a former refugee. Language and Intercultural Communication, 20(2), 110-124.

https://doi.org/10.1080/14708477.2020.1722147

Department of Labour. (2007). Settlement National Action Plan: New Zealand Settlement Strategy. Wellington: Department of Labour.

Dries, N., Forrier, A., De Vos, A., \& Pepermans, R. (2014). Self-perceived employability, organizationrated potential, and the psychological contract. Journal of Managerial Psychology, 29(5), $565-581$.

Duff, P. A. (2015). Transnationalism, multilingualism, and identity. Annual Review of Applied Linguistics, 35, 57-80.

Eastmond, M. (2007). Stories as lived experience: Narratives in forced migration research. Journal of Refugee Studies, 20(2), 248-264.

Finlay, L. (2012). Five lenses for the reflexive interviewer. In J. F. Gubrium, J. A. Holstein, A. B. Marvasti, \& K. D. McKinney (Eds.), The Sage handbook of interview research (2nd ed., pp. 317-331). Thousand Oaks, CA: Sage Publications.

Fraser, N. (2003). Social justice in the age of identity politics: Redistribution, recognition and participation. In N. Fraser \& A. Honneth (Eds.), Redistribution or recognition. London: Verso. Fugate, M., Kinicki, A. J., \& Ashforth, B. E. (2004). Employability: A psycho-social construct, its dimensions, and applications. Journal of Vocational Behavior, 65, 14-38.

Gabrielatos, C., \& Baker, P. (2008). Fleeing, sneaking, flooding-A corpus analysis of discursive constructions of refugees and asylum seekers in the UK press 1996-2005. Journal of English Linguistics, 36(1), 5-38.

Gee, J. P. (1990). Social linguistics and literacies: Ideology in discourses. London: Taylor \& Francis.

Greenbank, E. (2014). Othering and voice: How media framing denies refugees integration opportunities. Communication Journal of New Zealand, 14(1), 35-58.

Greenbank, E. (2019). Discursive navigation of employable identities in the narratives of former refugees (Doctoral Dissertation). Victoria University of Wellington, Wellington. 
Greenbank, E., \& Marra, M. (2020). Addressing societal discourses: negotiating an employable identity as a former refugee. Language and Intercultural Communication, 20(2), 110-124.

\section{https://doi.org/10.1080/14708477.2020.1722147}

Hinchliffe, G. W., \& Jolly, A. (2011). Graduate identity and employability. British Educational Research Journal, 37(4), 563-584.

Holmes, J. (2015). Joining a new community of workplace practice: Inferring attitudes from discourse. In E. Stracke (Ed.), Intersections: Applied Linguistics as a Meeting Place (pp. 2-21). Cambridge, UK: Cambridge Scholars Publishing.

Holmes, J., Joe, A., Marra, M., Newton, J., Riddiford, N., \& Vine, B. (2011). Applying linguistic research to real world problems: The case of the Wellington Language in the Workplace Project. In C. N. Candlin \& S. Sarangi (Eds.), Handbook in applied linguistics: Communication in the professions (pp. 533-549). Berlin: Mouton de Gruyter.

Holmes, J., \& Marra, M. (2017). You're a proper tradesman mate: Identity struggles and workplace transitions in New Zealand. In D. van de Mieroop \& S. Schnurr (Eds.), Identity Struggles: Evidence from workplaces around the world (pp. 127-146). Amsterdam: John Benjamins.

Holmes, L. (2001). Reconsidering graduate employability: The "graduate identity" approach. Quality in Higher Education, 7(2), 111-119.

Holmes, L. (2013). Realist and relational perspectives on graduate identity and employability: A response to Hinchliffe and Jolly. British Educational Research Journal, 39(6), 1044-1059.

Holstein, J. A., \& Gubrium, J. F. (1995). The active interview. Thousand Oaks, CA: Sage.

Korac, M. (2009). Remaking home: Reconstructing life, place and identity in Rome and Amsterdam. New York, NY: Berghahn Books.

Kunz, E. F. (1973). The refugee in flight: Kinetic models and forms of displacement. The International Migration Review, 7(2), 125-146.

Labov, W. (1973). The linguistic consequences of being a Lame. Language in Society, 2(1), 81-115.

Labov, W., \& Waletsky, J. (1967). Narrative analysis: Oral accounts of personal experiences. In J. Helm (Ed.), Essays on the verbal and visual arts: Proceedings of the 1967 annual spring 
Greenbank, E., \& Marra, M. (2020). Addressing societal discourses: negotiating an employable identity as a former refugee. Language and Intercultural Communication, 20(2), 110-124.

https://doi.org/10.1080/14708477.2020.1722147

meeting of the American Ethnological Society (pp. 12-44). Seattle, WA: University of Washington Press.

Ladegaard, H. J. (2012). The discourse of powerlessness and repression: Identity construction in domestic helper narratives. Journal of Sociolinguistics, 16(4), 450-482.

Ladegaard, H. J. (2017). The discourse of powerlessness and repression: Life stories of domestic Mmgrant workers in Hong Kong. Abington: Routledge.

Lagenhove, L. van, \& Harré, R. (1999). Introducing positioning theory. In R. Harré \& L. van Lagenhove (Eds.), Positioning theory (pp. 14-31). Oxford: Blackwell Publishing Ltd.

Lamba, N. K. (2003). The employment experiences of Canadian refugees: Measuring the impact of human and social capital on quality of employment. Canadian Review of Sociology/Revue Canadienne de Sociologie, 40(1), 45-64.

Lammers, E. (2007). Researching refugees: Preoccupations with power and questions of giving. Refugee Survey Quarterly, 26(3), 72-81.

Lanza, E. (2012). Empowering migrant identity: Agency in narratives of a work experience in Norway. Sociolinguistic Studies, 6(2), 285-307.

LaPointe, K. (2010). Narrating career, positioning identity: Career identity as a narrative practice. Journal of Vocational Behavior, 77(1), 1-9.

Lavy, I., \& Yadin, A. (2013). Soft skills - An important key for employability in the "shift to a service driven economy" era. International Journal of E-Education, e-Business, e-Management and e-Learning, 3(5), 416-420.

Lindemann, S., \& Mauranen, A. (2001). "It's just real messy": The occurrence and function of just in a corpus of academic speech. English for Specific Purposes, 20(1), 459-475.

Mann, S. (2010). A critical review of qualitative interviews in applied linguistics. Applied Linguistics, $32(1), 6-24$. 
Greenbank, E., \& Marra, M. (2020). Addressing societal discourses: negotiating an employable identity as a former refugee. Language and Intercultural Communication, 20(2), 110-124.

https://doi.org/10.1080/14708477.2020.1722147

Marlowe, J. M. (2010). Beyond the discourse of trauma: Shifting the focus on Sudanese refugees. Journal of Refugee Studies, 23(2), 183-198.

Marra, M. (2012). Disagreeing without being disagreeable: Negotiating workplace communities as an outsider. Journal of Pragmatics, 44(12), 1580-1590.

Marra, M., Holmes, J., \& Riddiford, N. (2011). New Zealand's Language in the Workplace project: Workplace communication for skilled migrants. In M. Krzanowski (Ed.), Current developments in English for work and workplace: Approaches, curricula and materials. Reading: Garnet Publishing.

Moreau, M.-P., \& Leathwood, C. (2006). Graduates' employment and the discourse of employability: A critical analysis. Journal of Education and Work, 19(4), 305-324.

Nayeri, D. (2017, April 4). The ungrateful refugee: 'We have no debt to repay.' The Guardian Online. Retrieved from https://www.theguardian.com/news/series/the-long-read?page=2

Pomerantz, A. (2012). Narrative approaches to second language acquisition. In C. A. Chapelle (Ed.), The encyclopedia of applied linguistics (pp. 1-7). Blackwell Publishing Ltd.

Pupavac, V. (2008). Refugee advocacy, Traumatic representations and political disenchantment. Government and Opposition, 43(2), 270-292.

Puvimanasinghe, T., Denson, L. A., Augoustinos, M., \& Somasundaram, D. (2014). Narrative and silence: How former refugees talk about loss and past trauma. Journal of Refugee Studies, 28(1), 69-92.

Reissner-Roubicek, S. (2017). Juggling "I"s and "we"s with "he"s and "she"s: Negotiating novice professional identities in stories of teamwork told in New Zealand job interviews. In D. van de Mieroop \& S. Schnurr (Eds.), Identity struggles: Evidence from workplaces around the world (pp. 57-78). Amsterdam: John Benjamins. 
Greenbank, E., \& Marra, M. (2020). Addressing societal discourses: negotiating an employable identity as a former refugee. Language and Intercultural Communication, 20(2), 110-124.

\section{https://doi.org/10.1080/14708477.2020.1722147}

Ricento, T. (2015). Refugees in Canada: On the loss of social capital. In B. Spolsky, O. Inbar, \& M. Tannenbaum (Eds.), Challenges for language education and policy: Making space for people (pp. 135-148). New York, NY: Routledge.

Richardson, P. (2000). Employability in a globalising economy: Implications for engineering training. Engineering Science and Education Journal, 9(4), 179-184.

Riddiford, N., \& Newton, J. (2010). Workplace talk in action-An ESOL resource. Wellington: Victoria University of Wellington.

Roberts, C. (2013). The gatekeeping of Babel: Job interviews and the linguistic penalty. In A. Duchêne, M. G. Moyer, \& C. Roberts (Eds.), Language, migration and social inequalities: A critical sociolinguistic perspective on institutions and work (pp. 81-94). Buffalo, NY: Multilingual Matters.

Sarbin, T. R. (1986). The narrative as root metaphor for psychology. In T. R. Sarbin (Ed.), Narrative psychology: The storied nature of human conduct (pp. 3-21). New York, NY: Praeger.

Schiffrin, D. (1996). Narrative as self-portrait: Sociolinguistic constructions of identity. Language in Society, 25(2), 167-203.

Spector-Mersel, G. (2011). Mechanisms of selection in claiming narrative identities: A model for interpreting narratives. Qualitative Inquiry, 17(2), 172-185.

Talmy, S. (2010). Qualitative interviews in applied linguistics: From research instrument to social practice. Annual Review of Applied Linguistics, 30, 128-148.

Tomlinson, M. (2010). Investing in the self: Structure, agency and identity in graduates' employability. Education, Knowledge and Economy, 4(2), 73-88.

Trudgill, P. (1974). The social differentiation of English in Norwich. Cambridge, UK: Cambridge University Press.

van de Mieroop, D. (2009). A rehearsed self in repeated narratives? The case of two interviews with a former hooligan. Discourse Studies, 11(6), 721-740. 
Greenbank, E., \& Marra, M. (2020). Addressing societal discourses: negotiating an employable identity as a former refugee. Language and Intercultural Communication, 20(2), 110-124.

https://doi.org/10.1080/14708477.2020.1722147

Vanhercke, D., De Cuyper, N., \& Peeters, E. (2013). Defining perceived employability: A psychological approach. Personnel Review, 43(4), 592-605.

Vine, B. (2017). Just and actually at work in New Zealand. In E. Friginal (Ed.), Studies in corpus-based sociolinguistics (pp. 199-219). New York, NY: Routledge.

Warner-Garcia, S. (2014). Laughing when nothing's funny: The pragmatic use of coping laughter in the negotiation of conversational disagreement. Pragmatics, 24(1), 157-180.

\footnotetext{
${ }^{1}$ The term skilled migrant here refers to tertiary-educated migrants who came to New Zealand voluntarily (in contrast to refugees' forced migration). The skilled migrants who the LWP team worked with had been unable to access employed in their desired professions for two years or more (Marra, 2012).

${ }^{2}$ All participant's names are pseudonyms

${ }^{3}$ Arwa requested that her country of origin not be specifically named in this research.

${ }^{4}$ We use physical here to describe Kelly's husband's restrictions on her whereabouts and activities rather than to suggest he used violence to do so. Whether he used physical force or power imbued by social structure (or both) is unknown to us.

${ }^{5}$ The other 'mechanisms' are inclusion, the reporting of events and periods of life that are compatible with the story's end point; and flattening, or the minimising of reported events and life periods in the life history, allowing the speaker to mention a 'fact' but simultaneously note its narrative insignificance (Spector-Mersel, 2011).

${ }^{6}$ For examples of these resources see these government websites, noting that resources are aimed and marketed at both employees and employers: https://worktalk.immigration.govt.nz/;

https://www.newzealandnow.govt.nz/work-in-nz/finding-work/job-interviews;

https://www.newzealandnow.govt.nz/resources/working-in-aged-care.
} 